Article

\title{
Sex, Sexuality, Sexual Offending and the Rights of Persons with Mental Disabilities
}

\author{
Michael L. Perlin ${ }^{1,2, *}$, Heather Ellis Cucolo ${ }^{1,2}$ and Alison J. Lynch ${ }^{2,3}$ \\ 1 New York Law School, 185 West Broadway, New York, NY 10013, USA; hcucolo@mdlpa.net \\ 2 Mental Disability Law and Policy Associates, 185 West Broadway, New York, NY 10013, USA; \\ alisonjlynch@gmail.com \\ 3 Disability Rights New York, 25 Chapel Street, Suite 1005, Brooklyn, NY 11201, USA \\ * Correspondence: mlperlin@mdlpa.net
}

Received: 31 August 2017; Accepted: 6 October 2017; Published: 18 October 2017

\begin{abstract}
Although the legal issues related to sexual autonomy and sexual offending are significantly different, the resistance to providing adequate and effective counsel and the employment of the vividness heuristic (to privilege anecdote and reject valid and reliable research) is similar in both cases. The past forty years has seen an explosion of interest in mental disability law, and a significant expansion of rights for the population of persons with mental disabilities, both in institutions and the community, during which the society has witnessed a revolution in American mental disability law. It saw the first broad-based, federal civil rights statutes enacted on behalf of persons with mental disabilities. It witnessed the creation of a "patients' bar" to provide legal representation to such persons. But this revolution largely bypassed persons seeking to argue for sexual autonomy and seeking to apply procedural and substantive due process to matters involving invocation of the sexually violent predator status. However, at the same time that all this happened, another parallel set of developments has had a profound application on mental disability law-on case law, statutes, administrative regulations and lawyers' roles. The expansion of the school of legal analysis known as therapeutic jurisprudence has caused scholars to reconsider many of the basic principles of this area of law, and it is critical that any analysis of mental disability law take the insights of this area seriously. The question we address in this paper is this: although there has been a general "revolution" in mental disability law, there are those whom it has not affected. To what extent does the law that governs sexual autonomy and that governs matters involving alleged sexually violent predators comport with these therapeutic jurisprudence principles? This paper considers that question.
\end{abstract}

Keywords: mental disability law; sexual autonomy; patients' rights; sexual offenders

One of the co-authors (M.L.P.) began a recent article (with another co-author) in this manner: "In this paper, we address a question that has been raised to each of us innumerable times since we began to practice law: 'How can you possibly represent to the court what your client is asking for?'”1 That article dealt with the responsibilities on counsel to ethically articulate their clients' positions on matters involving mental health treatment, even if that position was not the same as the one that counsel would have selected. In that article, we noted that a typical example might be, "how can you argue that your client has a right to sexual interaction?"2 In other articles and a book, two of the co-authors (M.L.P \& H.E.C) have written about counsel's profound ambivalence in representation of persons alleged to be sexually violent predators. ${ }^{3}$ Although the legal issues in these two areas of

\footnotetext{
Perlin and Weinstein (2016).

2 Id. at 75. Two of the co-authors (M.L.P. \& A.J.L.) have explored this issue extensively. See e.g., Perlin and Lynch (2016); Perlin and Lynch (2015a), Four-Letter Word; Perlin and Lynch (2014), Sexless Patients.

3 See e.g., Perlin and Cucolo (2017a); Cucolo and Perlin (2015).
} 
law-sexual autonomy and sexual offending—are significantly different, the resistance to providing adequate and effective counsel and the employment of the vividness heuristic (to privilege anecdote and reject valid and reliable research) ${ }^{4}$ is similar in both cases. ${ }^{5}$

The past forty years has seen an "explosion of interest" in mental disability law, ${ }^{6}$ and a significant expansion of rights for the population of persons with mental disabilities, both in institutions and the community. ${ }^{7}$ One of the co-authors (M.L.P.) put it starkly this way 15 years ago:

The past thirty years have witnessed a revolution in American mental disability law. This revolution is one that largely constitutionalized virtually every aspect of the involuntary civil commitment and release process, as well as most "pressure points" in the course of institutionalization (the right to treatment, the right to refuse treatment, the right to the least restrictive alternative course of treatment). It saw the first broad-based, federal civil rights statutes enacted on behalf of persons with mental disabilities. It witnessed the creation of a "patients' bar" to provide legal representation to such persons. ${ }^{8}$

But this revolution largely bypassed persons seeking to argue for sexual autonomy and seeking to apply procedural and substantive due process to matters involving invocation of the sexually violent predator status. By way of example, the treatment standards established in the historic institutional right to treatment case of Wyatt $v$. Stickney ${ }^{9}$ - the first broad-based law reform case granting a right to treatment to institutionalized psychiatric patients ${ }^{10}$ - guaranteed such individuals the right to reasonable interaction with members of the opposite sex. ${ }^{11}$ Of the many states that adopted the Wyatt standards as bases of their Patients' Bills of Rights, however, only four adopted this portion of the standards. ${ }^{12}$ There has also virtually no follow-up litigation based upon any of the statutes that do provide for this right, and only a scattering of cases has been litigated anywhere that has sought to vindicate this right. ${ }^{13}$

People with mental disabilities, who allegedly violate sex act-related laws, often face harsh consequences that fail to account for disability. For example, individuals who are civilly committed to facilities for sexually violent predators — the most despised members of society ${ }^{14}$-regularly face a lifetime of maximum security confinement (often without the benefit of counsel or a jury trial prior to this institutionalization) ${ }^{15}$ as a result of the Supreme Court's pretextual decision in Kansas v. Hendricks, ${ }^{16}$ enforcing social control in punitive ways under the guise of the beneficence of civil commitment. ${ }^{17}$ Although a diagnosis of a mental disability is a necessary component of the civil commitment statute, actual treatment falls short of properly addressing the issues. ${ }^{18}$ Scholars and

The vividness heuristic is the cognitive-simplifying device through which a "single vivid, memorable case overwhelms mountains of abstract, colorless data upon which rational choices should be made" (Perlin 1997a, p. 1417). (In this context, one vivid, negative anecdote-perhaps even an apocryphal one with no basis in fact-overwhelms an extensive contrary statistical database (Perlin 2009, p. 637)).

5 This resistance is replicated in the attitudes of law students. See Perlin and Lynch (2015b, pp. 217-18): The notion that patients have ... a right [to sexual autonomy] —and that this right may be found in some state patients' bills of rights ... —strikes many students as incredulous. See also, e.g., Cucolo and Perlin (2013, p. 216) (discussing the widespread belief that television programs such as Law \& Order: SVU-alleging a near 100\% recidivism rate among sex offenders-are accurate). See e.g., Perlin and Cucolo (2017b).

See $i d ., \S 1-2.1 .1$. For considerations of the major developments since 1990, see id., §§ 12-2.1 to 1-2.2.7.

Perlin (2002).

344 F. Supp. 373 (M.D. Ala. 1972), aff'd sub nom. Wyatt v. Aderholt, 503 F.2d 1305 (5th Cir. 1974).

Perlin and Cucolo (2017b), supra note 6, §§ 7-3.1 to 7-3.1.15.

Wyatt, 344 F. Supp. at 381.

2 See Perlin (1997b, pp. 947, 965); Perlin and Lynch (2016), supra note 2, at 29-30.

13 See, e.g., Gary W. V. Louisiana, 437 F. Supp. 1209, 1228-29 (E.D. La. 1976) (following Wyatt); Davis v. Watkins, 384 F. Supp. 1196, 1206 (N.D. Ohio 1974) (following Wyatt).

14 Geraghty (2007).

15 See Perlin and Cucolo (2017b), supra note 6, §§ 5-4.6 to 5-4.7.

16521 U.S. 346 (1997) (holding that a Sexually Violent Predator Act is constitutional even though additional confinement follows prison time). See generally, Perlin (1998).

17 Perlin (2003, pp. 199-200).

18 See generally, Lindsay (2005) (citing lack of sexual knowledge and social skills as a cause of sex offending behavior). 
legislators must be cognizant of the presence of disability, and understand how it influences behavior. An awareness and understanding of these issues will allow for better effective strategies in public safety rehabilitation.

We have chosen in this article to discuss these two seemingly-disparate questions together, as we believe that society's responses to the issues raised flow from similar attitudes-about sexuality and disability-and that "twinning" developments in these areas may give us some insights to the roots of these attitudes and to potential means of remediation.

At the same time that all this happened in these areas of law, another parallel set of developments has had a profound application on all aspects of mental disability law-on case law, statutes, administrative regulations and lawyers' roles. The expansion of the school of legal analysis known as therapeutic jurisprudence has caused scholars to reconsider many of the basic principles of this area of law, and it is critical that any analysis of mental disability law take the insights of this area seriously. ${ }^{19}$

Therapeutic jurisprudence "look[s] at law as it actually impacts people's lives" 20 and assesses law's influence on "emotional life and psychological well-being." ${ }^{21}$ It mandates that "law should value psychological health, should strive to avoid imposing anti-therapeutic consequences whenever possible, and when consistent with other values served by law, should attempt to bring about healing and wellness." 22 Its ultimate aim is to determine whether legal rules, procedures, and lawyer roles can or should be reshaped to enhance their therapeutic potential while not subordinating due process principles. $^{23}$

It embodies what Professor Amy Ronner has characterized as "the three Vs"—voice, validation and voluntariness: ${ }^{24}$

What "the three Vs" commend is pretty basic: litigants must have a sense of voice or a chance to tell their story to a decision maker. If that litigant feels that the tribunal has genuinely listened to, heard, and taken seriously the litigant's story, the litigant feels a sense of validation. When litigants emerge from a legal proceeding with a sense of voice and validation, they are more at peace with the outcome. Voice and validation create a sense of voluntary participation, one in which the litigant experiences the proceeding as less coercive. ${ }^{25}$

The question, then, to be asked is this: although there has been a general "revolution" in mental disability law, there are those whom it has not affected. To what extent does the law that governs sexual autonomy and that governs matters involving alleged sexually violent predators comport with these therapeutic jurisprudence principles? And how might a focus on therapeutic jurisprudence offer some remediation? It is to these questions we turn next.

\section{Patients' Rights: Competency and Sexual Autonomy}

An article published in early 2014 in a peer-reviewed scientific journal began with a startling comment: "The recognition that individuals with disabilities have a desire for sexual relationships with

\footnotetext{
See e.g., Perlin and Cucolo (2017c, pp. 1475-76).

Winick (2009).

Wexler (2000).

Winick (2003).

Perlin (2005, p, 751). For an important recent paper emphasizing the necessary integral relationship between therapeutic jurisprudence and due process, see Stobbs (2017).

24 Ronner (2008). Certainly, in the context of the topic of this paper, these factors must be considered along with issues such as public safety and individual welfare, but we believe that the basic precepts of therapeutic jurisprudence still control. See generally, Birgden and Perlin (2008). See also e.g., Dickie (2008, p. 460) ("The TJ Model allows for a more therapeutic approach to managing criminal behavior in which all invested parties, including psychologists, lawyers, and correctional officers can balance the rights of the offenders against public safety").

25 Ronner (2002, pp. 94-95) (internal citations omitted).
} 
other people is a relatively new concept in the scientific community." ${ }^{26}$ This observation-wildly at odds with much of the literature in the field ${ }^{27}$-exemplifies the confusion and misinformation that permeates this area of law and policy. The baseline, rather, for any scholarly inquiry into this subject, must be that "individuals [with disabilities] have the same needs for intimate relationships and sexual expression as everyone else." 28

With the growth in the field of mental disability law over the past 50 years, very few topics involving persons with mental illness remain taboo or off limits to scholars and judges facing these issues daily. However, discussions of the question of whether persons with mental disabilities have a right to voluntary sexual interaction often touches a raw nerve in conversations about mental disability law even with those who are practicing in the field, The discomfort that people feel in examining this topic is further exacerbated when discussing individuals who are institutionalized. Our attitudes toward the sexuality of persons with mental disabilities can often be divided into two categories, at odds with each other and with our understanding of the importance of human sexuality and autonomy to engage in consensual sexual activity:

Society tends to infantilize the sexual urges, desires, and needs of the mentally disabled. Alternatively, they are regarded as possessing an animalistic hypersexuality, which warrants the imposition of special protections and limitations on their sexual behavior to stop them from acting on these "primitive" urges. By focusing on alleged "differentness", we deny their basic humanity and their shared physical, emotional, and spiritual needs. By asserting that theirs is a primitive morality, we allow ourselves to censor their feelings and their actions. By denying their ability to show love and affection, we justify this disparate treatment. ${ }^{29}$

All these tensions are heightened in cases involving institutionalized persons, in which patient desires and provider discomforts must be acknowledged and recalibrated. ${ }^{30}$ Although this is often a difficult subject to raise, even among those familiar and comfortable with other aspects of mental disability, it is one that must be raised in order to comport with therapeutic jurisprudence, and legal standards. Dignity concerns and rights violations will occur if there is not a full understanding of the importance of the ability for persons with mental illness to practice free sexual expression.

In this discussion, it is critical to start with the assumption that all individuals have the capacity to consent to sexual relations, and that the presence of a mental disorder, in itself, does not mean that the individual lacks this capacity. ${ }^{31}$ With this as a "given", it is first necessary to understand the different modes of analysis to be engaged in determining capacity and competency. Capacity "refers to an individual's actual ability to understand, appreciate, and form a relatively rational intention with regard to some act." 32 Competency is a legal assessment that varies based on the act or decisionmaking that is being considered. ${ }^{33}$ Both of these concepts are intertwined in assessing the extent to which a person can exercise informed consent.

26 Gilmour et al. (2014) (emphasis added). Many other issues are raised in the context of individuals with physical disabilities. See e.g., Bahner (2012) (discussing "intimacy influenced activities" such as genital shaving). By way of example, there has been some preliminary exploration of the question of the impact of certain physical disabilities on a woman's ability to have orgasms (p. 347). See e.g., Glass (1999).

27 See Perlin and Lynch (2015a), Four-Letter Word, supra note 2.

28 Werner (2012). Professor Werner's focus was on persons with intellectual disabilities but there is nothing in the literature that suggests persons with mental illness/psychosocial disabilities are any different in this regard. We use the phrase "mental disabilities" to encompass both groups.

29 Perlin (1993, p. 537). For a subsequent consideration of the impact of this infantilization, see Benedet and Grant (2007).

30 See e.g., Tennille (2013).

31 Mental Welfare Commission of Scotland (2007).

32 Bisbing (2007). On why inquiries into capacity are an insufficient basis for decisionmaking about persons with mental disabilities engaging in sexual interactions, see Dimopoulos (2012).

33 See generally, Perlin et al. (2008). 
There is also the difficulty of establishing "clinical" competency, for those persons who are institutionalized. There is no standard that clinicians can apply when determining competency; in fact, it is a very fluid determination. In a survey of institutions' views on their ability to handle ethical concerns of patient sexual expression, author Eric Wright found, "aside from formal legal declarations of incompetence, establishing competence to engage in sexual activity during treatment is further complicated by the dynamic nature of psychiatric symptoms, variation in patients' sexuality-related knowledge and experience, and institutional policies." ${ }^{\prime 34}$ Moreover, in certain locations, the relationship between sexuality and privacy is "directly related to assessments about ... competence." 35

The reality is, however, that we too often fail to take any of this into account and instead superimpose a societal presumption of incompetency, ${ }^{36}$ a "damaging message" when applied to any aspects of a person with a mental disability. ${ }^{37}$ This, more than anything else, leads to the confusion, dissonance, and tension in this area of law, society, and personhood. This type of presumption is directly at odds with a therapeutic jurisprudence-based analysis of this issue. The questions that must be addressed here are these: are persons with mental disabilities given this sort of autonomy in their sexual decisionmaking? Are Professor Ronner's "3 V's" complied with? Generally, where incompetency is presumed and individuals who are institutionalized are treated either as asexual or hypersexual based only on their diagnosis of mental illness, we are far from establishing an ethos of care that takes into account the importance of sexuality for everyone, and keeps the sensitive nature of the topic in mind while crafting policies and procedures that empower and educate, rather than demonize or demoralize this population. ${ }^{38}$

\section{Sexually Violent Predator Law and Therapeutic Jurisprudence}

Are the people before the court in this cohort of cases-the most despised individuals in the nation-"worthy" of the assignment of counsel, of the right to constitutional amendments, of the right to a fair trial? ${ }^{39}$

Currently, no other population in our criminal and civil legal system is more despised, more vilanized, more subject to media mis-representation and more likely to be denied basic human rights. Factual evidence regarding this population has been greatly skewed to satisfy political agendas and community outcries of retribution. ${ }^{40}$ One of the results of such outcries was the enactment of a legislative scheme that teetered on the border of civil and criminal law, of which sole purpose was to indefinitely contain individuals labeled sexual predators. ${ }^{41}$ Twenty individual states and the federal government have enacted laws confining individuals who have been adjudicated as "sexually violent predators" to civil commitment facilities post incarceration and/or conviction. ${ }^{42}$ Additionally, in many jurisdictions, offenders who are returned to the community are restricted and monitored

34 Wright et al. (2012). For a consideration of how institutional living inevitably shapes policies related to masturbation, see Gill (2012).

35 Id.

36 On similar incorrect presumptions of incompetency in the law, see e.g., Rodham (1973) (presumed incompetency in children); Lucas (2013) (presumed physical incompetency of pregnant teachers). On how lawyers often impermissibly engage in such a presumption of incompetency with regard to their institutionalized clients, see Perlin (2008, p. 262). There is no question that not even a judgment of involuntary commitment can act as an adjudication of incompetency. See e.g., N.J. STAT. ANN $\S 30: 4-24.2(\mathrm{c})$.

37 (Best 2012, p. 488).

38 See e.g., Perlin and Lynch (2014), Sexless Patients, supra note 2; Perlin and Lynch (2016), supra note 2.

39 See e.g., Perlin and Cucolo (2017b), supra note 6, §§ 5-4.6 to 5-4.7.

40 See e.g., Cucolo and Perlin (2012).

41 Hendricks, 521 U.S. at 371-73 (Kennedy, J., concurring) ("[n]otwithstanding its civil attributes, the practical effect of the Kansas law may be to impose confinement for life").

42 Carpenter and Beverlin (2012) (Arizona, California, Florida, Illinois, Iowa, Kansas, Massachusetts, Minnesota, Missouri, Nebraska, New Hampshire, New Jersey, New York, North Dakota, Pennsylvania, South Carolina, Texas, Virginia, Washington, Wisconsin, and the United States (the Adam Walsh Child Protection and Safety Act of 2006 authorized the federal government to institute a civil commitment program for federal sex offenders (42 U.S.C. $§ 16971)$ ). 
under community notification, registration and residency limitations. ${ }^{43}$ In more recent years, courts and scholars have begun to question the constitutionality of the laws and statutes as applied, ${ }^{44}$ but it is on with a guaranteed right to quality counsel, that those questions will continue to be effectively raised in the courts.

Each civil commitment statute has the same basic requirements- a qualifying offense, a current mental abnormality or personality disorder, the likelihood of committing future acts of sexual violence and a finding of a nexus between all three. Jurisdictions vary on the availability and constitutionality of the Sixth Amendment right to counsel at trial ${ }^{45}$ and although securing a constitutional right to counsel in civil commitment is an initial step, it is crucial that we not merely consider the right to counsel but discuss that right in combination with the quality of counsel and counsel's resources and knowledge in this area of the law. Effective counsel in these proceedings must be able to combat unique and complex challenges, including, for instance, the chilling effect on vigorous representation of such a despised population, and the effect of the legal process on the individual.

Thus, to what extent can therapeutic jurisprudence better inform legal practices to insure that adequate counsel is provided in consideration of Professor Ronner's principles of voluntariness, voice and validation ${ }^{46}$

Although it may appear that the principles behind voluntariness and voice are difficult to maintain when they are weighed with the ultimate goal of public safety, ${ }^{47}$ we believe that voice and voluntariness need not be adverse to the goals of public safety. ${ }^{48}$ The public policy approach to sex offender treatment which is currently treatment-as-management (deterrence and community rights) undermines treatment-as-rehabilitation (autonomy and offender rights). ${ }^{49}$ Understanding and helping to reduce the impact of the harms of that arise out of the civil commitment process can benefit the individual and decrease the potential for recidivism. ${ }^{50}$ A primary focus on deterrence and community rights can lead to future unemployment, homelessness, shame, depression and anxiety, disconnection from social supports, and inadequate treatment-outcomes that have been shown to increase potential for recidivism. ${ }^{51}$ Persons in sex offender civil commitment are often denied their basic privacy rights, leading to feelings of infantilization. ${ }^{52}$ The conditions under which they live reinforce the knowledge of compromised social status and stigmatized social role as pariahs of the communtity. ${ }^{53}$

Even the simple act of having a zealous advocate can offer the client a sense of self-worth and personal value. Sexual violent predator litigation requires lawyers to be able to understand, contextualize and effectively cross-examine and rebut their adversary's position. Even a cursory examination of cases litigated on the right to counsel issue demonstrates the demand for a TJ approach to representation and to litigation. ${ }^{54}$ Lawyers must continue to compel the court to

43 See generally, Cucolo and Perlin (2013), supra note 5, at 218.

44 See generally, Perlin and Cucolo (2017b), supra note 6, Chapter 5.

45 Commitment of Dodge, 989 N.E.2d 1159 (Ill. App. 2013) (although proceedings governing a petition alleging that a defendant is a "sexually violent person" under the Sexually Violent Persons Commitment Act are civil in nature, the Act provides a defendant with the right to effective assistance of counsel as provided in Strickland).

46 Ronner (2002), supra note 25, at 94-95.

47 But see Birgden and Perlin (2008), supra note 24, and Dickie (2008), supra note 24.

48 See e.g., King (2008): Therapeutic jurisprudence has suggested reforms to minimise the law's negative effects on wellbeing and to promote its wellbeing-related goals such as crime victims' safety and health, injured workers' rehabilitation and broken families' welfare. 49 See Birgden and Cucolo (2011).

50 Id. (Treatment-as-management has anti-therapeutic consequences that increase the risk to re-offend).

51 See e.g., Cucolo and Perlin (2012), supra note 40, at 2. On how shame-based policies violate therapeutic jurisprudence, see Perlin and Weinstein (2014). On how they do this in a sex offender-specific context, see Cucolo and Perlin (2017).

52 See Duwe (2013).

53 Id.

54 For a comprehensive consideration of state-by-state practices, see (NDAA 2012). See generally, In re Detention of Bailey, 740 N.E.2d 1146 (Ill. App.Ct.2000) (present commitment proceedings were civil in nature and thus were not improperly used by state to subject offender to greater punishment than was imposed pursuant to plea bargain). In re Detention of Campbell, 986 P.2d 771 (Wash. App. 1999) (en banc), cert. denied, 531 U.S. 1125 (2001) (explaining that because civil commitment is not criminal punishment, it was not a foregone conclusion that respondent would be civilly committed, thus commitment, like sex offender registration, is a collateral consequence of pleading guilty and does not violate the plea 
reject unconstitutional procedures and punitive measures that have not been found to reduce recidivism. ${ }^{55}$ Further, lawyers need to be educated in not only courtroom strategies but treatment and care strategies as well. For instance, if counsel were to be familiar with such approaches as the Risk-Needs-Responsibility Model or the Good Lives model ${ }^{56}$ _embodying approaches that go "beyond the legalistic skills of the lawyers"57 — the TJ value of "zealous counseling" might be better served. ${ }^{58}$ In particular the Good Lives model: (1) conceptualizes dynamic risk factors merely as "red flags" indicating human needs are being met in anti-social rather than pro-social ways; (2) provides a positive strength-based approach to sex offenders in viewing them as interdependent and so reliant on the good will of others to support them; (3) outlines the skills and capacities necessary to enhance treatment readiness; and (4) explicitly addresses practitioner attitudes toward offenders and the impact upon the therapeutic alliance. ${ }^{59}$

\section{Conclusions}

Developments in these two areas of the law reflect societal fears and unease about the relationships between disability and sexuality, whether that relationship is "positive" (sexual autonomy) or "negative" (sexual offending). Both the law and social attitudes about both these topics-sexual autonomy and sexual offending-reject the basic therapeutic jurisprudence principles. If TJ counsels us-as it does-that the law should value and promote an "ethic of care,"60 then it is clear that sexuality and sexual offending law fails miserably. Certainly, the "voice" required in Professor Ronner's formulation of TJ is missing. ${ }^{61}$ Our prejudices and our fears-both spoken and unspoken-dominate this area of law and policy; 62 and it is essential we confront this as we approach these issues if the "revolution" in domestic American mental disability law that began in the early 1970 s $^{63}$ is to have any reality for the cohorts of individuals we discuss here.

Author Contributions: The three co-authors participated equally in the creation of and writing of this paper.

Conflicts of Interest: The authors declare no conflict of interest.

\section{References}

Bahner, Julia. 2012. Legal Rights or Simply Wishes? The Struggle for Sexual Recognition of People with Physical Disabilities Using Personal Assistance in Sweden. Sexuality and Disability 30: 337-56. [CrossRef]

Benedet, Janine, and Isabel Grant. 2007. Hearing the Sexual Assault Complaints of Women with Mental Disabilities: Evidentiary and Procedural Issues. McGill Law Review 52: 515-52.

Best, Eli. 2012. Atypical Actors and Tort Law's Expressive Function. Marquette Law Review 96: 461-515. [CrossRef] Birgden, Astrid. 2004. Therapeutic Jurisprudence and Sex Offenders: A Psycho-Legal Approach to Protection. Sexual Abuse: A Journal of Research and Treatment 16: 351-64. [CrossRef] [PubMed]

agreement); Matter of Hay, 953 P.2d 666 (Kan. App. 1998) (finding the "plea agreement is immaterial as far as proceedings under the Act are concerned" where the commitment is based on a defendant's mental ailment and present dangerousness); People v. Moore, 81 Cal.Rptr.2d 658, 661 (1998) (holding any commitment defendant might suffer under the sexual violent predator act would not be a direct consequence of his plea); In re Kunshier, 521 N.W.2d 880 (Minn.Ct.App.1994) (finding that county did not violate plea agreement by invoking civil commitment statute against patient because it is not criminal punishment but civil treatment).

55 MacKenzie (2006). One recent state study (Minnesota) has concluded that just nine percent of civilly committed sex offenders would have been reconvicted of a sex offense had they been released to the community.

56 Ward and Maruna (2007), and Birgden (2004).

57 Dewhurst (2013, p. 1002).

58 Id. at 972, quoting Ward (2008).

59 See e.g., Birgden and Cucolo (2011), supra note 49, at 303.

60 See e.g., Winick and Wexler (2006); Wexler (2007)

61 See Cucolo and Perlin (2015), supra note 3, at 167.

62 Perlin and Lynch (2014), Sexless Patients, supra note 2, at 299-300.

63 Perlin (2002), supra note 8, at 423. 
Birgden, Astrid, and Heather Ellis Cucolo. 2011. The Treatment of Sex Offenders: Evidence, Ethics and Human Rights. Sexual Abuse A Journal of Research and Treatment 23: 295-313. [CrossRef] [PubMed]

Birgden, Astrid, and Michael L. Perlin. 2008. "Tolling for the Luckless, the Abandoned and Forsaked": Community Safety, Therapeutic Jurisprudence and International Human Rights Law as Applied to Prisoners and Detainees. Legal and Criminological Psychology 13: 231-43. [CrossRef]

Bisbing, Steven B. 2007. Competency and Capacity: A Primer. In Legal Medicine, 7th ed. Edited by American College of Legal Medicine. Maryland Heights: Mosby, p. 325.

Carpenter, Catherine L., and Amy E. Beverlin. 2012. The Evolution of Unconstitutionality in Sex Offender Registration Laws. Hastings Law Journal 63: 1071-134.

Cucolo, Heather Ellis, and Michael L. Perlin. 2012. Preventing Sex-Offender Recidivism through Therapeutic Jurisprudence Approaches and Specialized Community Integration. Temple Political and Civil Rights Law Review 22: 1-42. [CrossRef]

Cucolo, Heather Ellis, and Michael L. Perlin. 2013. "They're Planting Stories in the Press": The Impact of Media Distortions on Sex Offender Law and Policy. University of Denver Criminal Law Review 3: 185-246. [CrossRef]

Cucolo, Heather Ellis, and Michael L. Perlin. 2015. "Far from the Turbulent Space": Considering the Adequacy of Counsel in the Representation of Individuals Accused of Being Sexually Violent Predators. University of Pennsylvania Journal of Law and Social Change 15: 125-68. [CrossRef]

Cucolo, Heather Ellis, and Michael L. Perlin. 2017. Promoting Dignity and Preventing Shame and Humiliation by Improving the Quality and Education of Attorneys in Sexually Violent Predator (SVP) Civil Commitment Cases. Florida Journal of Law and Public Policy. forthcoming. [CrossRef]

Dewhurst, Dale. 2013. Understanding the Legal Client's Best Interests: Lessons from Therapeutic Jurisprudence and Comprehensive Justice. Phoenix Law Review 6: 963-1016.

Dickie, Ida. 2008. Ethical Dilemmas, Forensic Psychology, and Therapeutic Jurisprudence. Thomas Jefferson Law Review 30: 455-61.

Dimopoulos, Andreas. 2012. Let's Misbehave: Intellectual Disability and Capacity to Consent to Sex. Paper presented at Society of Legal Scholars, Bristol, UK, September 11-14; Available online: http:/ / papers.ssrn. com/sol3/papers.cfm?abstract_id=2332259 (accessed on 15 August 2017).

Duwe, Grant. 2013. To What Extent Does Civil Commitment Reduce Sexual Recidivism? Estimating the Selective Incapacitation Effects in Minnesota. Journal of Criminal Justice 42: 193-202. Available online: http: / / www.sciencedirect.com/science/article/pii/S0047235213000482 (accessed on 10 August 2017). [CrossRef]

Geraghty, Sarah. 2007. Challenging the Banishment of Registered Sex Offenders from the State of Georgia: A Practitioner's Perspective. Harvard Civil Rights-Civil Liberties Law Review 42: 513-57.

Gill, Michael. 2012. Sex Can Wait, Masturbate: The Politics of Masturbation. Sexualities 15: 472-93. [CrossRef]

Gilmour, Laura, Veronica Smith, and Melike Schalomon. 2014. Sexuality and ASD: Current State of the Research. In Comprehensive Guide to Autism. Edited by Vinood B. Patel, Victor R. Preedy and Colin R. Martin. Berlin: Springer, p. 569.

Glass, Clive. 1999. Sexual Problems of Disabled Patients. BMJ 171: 107-9.

King, Michael S. 2008. Restorative Justice, Therapeutic Jurisprudence and the Rise of Emotionally Intelligent Justice. Melbourne University Law Review 32: 1096-126.

Lindsay, William R. 2005. Model Underpinning Treatment for Sex Offenders with Mild Intellectual Disability: Current Theories of Sex Offending. Mental Retardation 43: 428-41. [CrossRef]

Lucas, Lauren Sudeall. 2013. A Dilemma of Doctrinal Design: Rights, Identity and the Work-Family Conflict. FIU Law Review 8: 379-404.

MacKenzie, Doris Layton. 2006. What Works in Corrections: Reducing the Criminal Activities of Offenders and Delinquents. Cambridge: Cambridge University Press, pp. 333-34.

Mental Welfare Commission of Scotland. 2007. Consenting Adults? Guidance for Professionals and Carers When Considering Rights and Risks in Sexual Relationships Involving People with a Mental Disorder. Edinburgh: Mental Welfare Commission of Scotland, p. 4.

NDAA. 2012. Civil Commitment of Sex Offenders. Available online: http://www.ndaa.org/pdf/Sex\% 20Offender\%20Civil\%20Commitment-April\%202012.pdf (accessed on 15 August 2017).

Perlin, Michael L. 1993. Hospitalized Patients and the Right to Sexual Interaction: Beyond the Last Frontier? NYU Review of Law and Social Change 20: 517-47. 
Perlin, Michael L. 1997a. "The Borderline Which Separated You from Me": The Insanity Defense, the Authoritarian Spirit, the Fear of Faking, and the Culture of Punishment. Iowa Law Review 82: 1375-426.

Perlin, Michael L. 1997b. Make Promises by the Hour: Sex, Drugs, the ADA, and Psychiatric Hospitalization. DePaul Law Review 46: 947-85.

Perlin, Michael L. 1998. There's No Success like Failure/and Failure's No Success at All: Exposing the Pretextuality of Kansas v. Hendricks. Northwestern University Law Review 92: 1247-77.

Perlin, Michael L. 2002. Chimes of Freedom: International Human Rights and Institutional Mental Disability Law. New York Law School Journal of International and Comparative Law 21: 423-34.

Perlin, Michael L. 2003. Therapeutic Jurisprudence and Outpatient Commitment: Kendra's Law as Case Study. Psychology, Public Policy, and Law 9: 183-208. [CrossRef] [PubMed]

Perlin, Michael L. 2005. "And My Best Friend, My Doctor, Won't Even Say What It Is I've Got": The Role and Significance of Counsel in Right to Refuse Treatment Cases. San Diego Law Review 42: 735-55.

Perlin, Michael L. 2008. "I Might Need a Good Lawyer, Could Be Your Funeral, My Trial”: A Global Perspective on the Right to Counsel in Civil Commitment Cases, and Its Implications for Clinical Legal Education. Washington University Journal of Law and Policy 28: 241-64.

Perlin, Michael L. 2009. "Simplify You, Classify You": Stigma, Stereotypes and Civil Rights in Disability Classification Systems. Georgia State University Law Review 25: 607-40.

Perlin, Michael L., and Heather Ellis Cucolo. 2017a. Shaming the Constitution: The Detrimental Results of Sexual Violent Predator Legislation. Philadelphia: Temple University Press.

Perlin, Michael L., and Heather Ellis Cucolo. 2017b. Mental Disability Law: Civil and Criminal, 3rd ed. New York: LexisNexis, pp. 1-2.

Perlin, Michael L., and Heather Ellis Cucolo. 2017c. “Tolling for the Aching Ones Whose Wounds Cannot Be Nursed": The Marginalization of Racial Minorities and Women in Institutional Mental Disability Law. The Journal of Gender, Race E Justice 20: 431-58.

Perlin, Michael L., and Alison J. Lynch. 2014. "All His Sexless Patients": Persons with Mental Disabilities and the Competence to Have Sex. Washington Law Review 89: 257-300. [CrossRef]

Perlin, Michael L., and Alison J. Lynch. 2015a. “Love is Just a Four-Letter Word”: Sexuality, International Human Rights and Therapeutic Jurisprudence. Canadian Journal of Comparative and Contemporary 1: 9-48. [CrossRef]

Perlin, Michael L., and Alison J. Lynch. 2015b. How Teaching about Therapeutic Jurisprudence Can Be a Tool of Social Justice, and Lead Law Students to Personally and Socially Rewarding Careers: Sexuality and Disability as a Case Example. Nevada Law Journal 16: 209-25. [CrossRef]

Perlin, Michael L., and Alison J. Lynch. 2016. Sexuality, Disability, and the Law: Beyond the Last Frontier? Berlin: Springer.

Perlin, Michael L., and Naomi Weinstein. 2014. "Friend to the Martyr, a Friend to the Woman of Shame": Thinking about the Law, Shame and Humiliation. Southern California Review of Law and Social Justice 24: 1. [CrossRef]

Perlin, Michael L., and Naomi Weinstein. 2016. "Said I, ‘But You Have No Choice'": Why a Lawyer Must Ethically Honor a Client's Decision about Mental Health Treatment Even if It Is Not What S/he Would Have Chosen. Cardozo Public Law Policy \& Ethics Journal 15: 73.

Perlin, Michael L., Pamela R. Champine, Henry A. Dlugacz, and Mary Connell. 2008. Competence in the Law: From Legal Theory to Clinical Application. Hoboken: John Wiley \& Sons.

Rodham, Hillary. 1973. Children under the Law. Harvard Educational Review 43: 487-514. [CrossRef]

Ronner, Amy D. 2002. Songs of Validation, Voice, and Voluntary Participation: Therapeutic Jurisprudence, Miranda and Juveniles. University of Cincinnati Law Review 71: 89-114.

Ronner, Amy D. 2008. The Learned-Helpless Lawyer: Clinical Legal Education and Therapeutic Jurisprudence as Antidotes to Bartleby Syndrome. Touro Law Review 24: 601-96.

Stobbs, Nigel. 2017. Therapeutic Jurisprudence and Due Process-Consistent in Principle and Practice. Journal of Judicial Administration 26: 248-64.

Tennille, Julie. 2013. Addressing the Intimacy Interests of People with Mental Health Conditions: Acknowledging Consumer Desires, Provider Discomforts, and System Denial (Monograph from the Temple University Collaborative on Community Inclusion of Individuals with Psychiatric Disabilities). Available online: http:/ / tucollaborative.org/pdfs/Toolkits_Monographs_Guidebooks/relationships_family_friends_ intimacy/intimacy.pdf (accessed on 15 April 2013). 
Ward, Robert. 2008. Criminal Defense Practice and Therapeutic Jurisprudence: Zealous Advocacy through Zealous Counseling: Perspectives, Plans and Policy. In Rehabilitating Lawyers: Principles of Therapeutic Jurisprudence for Criminal Law Practice. Edited by David B. Wexler. Durham: Carolina Academic Press, pp. 206-25.

Ward, Tony, and Shadd Maruna. 2007. Rehabilitation: Beyond the Risk Paradigm. Abingdon: Routledge, p. 46.

Werner, Shirli. 2012. Individuals with Intellectual Disabilities: A Review of the Literature on Decision-Making since the Convention on the Rights of Persons with Disabilities (CRPD). Public Health Reviews 34: 14-16. [CrossRef]

Wexler, David B. 2000. Practicing Therapeutic Jurisprudence: Psychological Soft Spots and Strategies. In Practicing Therapeutic Jurisprudence: Law as a Helping Profession. Edited by Dennis P. Stolle, David B. Wexler and Bruce J. Winick. Durham: Carolina Academic Press, p. 45.

Wexler, David B. 2007. Not Such a Party Pooper: An Attempt to Accommodate (Many of) Professor Quinn's Concerns about Therapeutic Jurisprudence Criminal Defense Lawyering. Boston College Law Review 48: 597-607.

Winick, Bruce. 2003. A Therapeutic Jurisprudence Model for Civil Commitment. In Involuntary Detention and Therapeutic Jurisprudence: International Perspective on Civil Commitment. Edited by Kate Diesfeld and Ian Freckelton. Farnham: Ashgate, pp. 23, 26.

Winick, Bruce J. 2009. Foreword: Therapeutic Jurisprudence Perspectives on Dealing with Victims of Crime. Nova Law Review 33: 535-43. [CrossRef]

Winick, Bruce J., and David B. Wexler. 2006. The Use of Therapeutic Jurisprudence in Law School Clinical Education: Transforming the Criminal Law Clinic. Clinical Law Review 13: 605-7.

Wright, Eric R., Heather McCabe, and Harold K. Kooreman. 2012. Institutional Capacity to Respond to the Ethical Challenges of Patient Sexual Expression in State Psychiatric Hospitals in the United States. Journal of Ethics in Mental Health 7: 1-5.

(C) 2017 by the authors. Licensee MDPI, Basel, Switzerland. This article is an open access article distributed under the terms and conditions of the Creative Commons Attribution (CC BY) license (http:/ / creativecommons.org/licenses/by/4.0/). 